This item was submitted to Loughborough's Research Repository by the author.

Items in Figshare are protected by copyright, with all rights reserved, unless otherwise indicated.

\title{
Diversity in an anti-immigration era: Theories, controversies, principles
}

PLEASE CITE THE PUBLISHED VERSION

https://doi.org/10.1177/1468796819866346

PUBLISHER

SAGE Publications

\section{VERSION}

AM (Accepted Manuscript)

\section{PUBLISHER STATEMENT}

This paper was accepted for publication in the journal Ethnicities and the definitive published version is available at https://doi.org/10.1177/1468796819866346. Users who receive access to an article through a repository are reminded that the article is protected by copyright and reuse is restricted to non-commercial and no derivative uses. Users may also download and save a local copy of an article accessed in an institutional repository for the user's personal reference.

\section{LICENCE}

In Copyright

\section{REPOSITORY RECORD}

Parvin, Phil. 2019. "Diversity in an Anti-immigration Era: Theories, Controversies, Principles". Loughborough University. https://hdl.handle.net/2134/13034393.v1. 


\section{Diversity in an Anti-Immigration Era: \\ Theories, Controversies, Principles}

If future historians of political thought were to look back on the late-20 in order to pinpoint exactly when many of the most influential theories of multiculturalism which dominated Anglo-American political theory at that time became untenable, at what point in those decades would they settle?

Some, of course, will argue that they've not, and that the theories that were produced then are as applicable and as persuasive now as ever. Others will argue that the normative responses to cultural and religious diversity provided by political theorists during that time were never helpful, and never really spoke to the lived experiences of citizens living in liberal democratic states; perhaps because they were too focused on understanding minority experiences through the lens of this or that ideology, or too committed to controversial principles like freedom or equality or individuality, or not committed to these principles enough; or grounded in a philosophical framework which missed the key issues, or provided analyses which led to unfeasible conclusions, or unworkable solutions, or which produced solutions which were held to apply to all states but which in fact were only applicable to certain states with specific constitutional or institutional arrangements. But while their individual merits might be open to debate, the fact that they assumed a central place in Anglo-American political theory in the years between, say, 1990 and 2010, and generated a vast amount of scholarship, is not. Theorists such as Will Kymlicka, Joseph Raz, John Rawls, Iris Marion Young, and James Tully established an uneasy yet very real consensus within mainstream political theory on the need for a definitive normative response to the political tensions arising out of the cultural and religious diversity that characterises contemporary liberal democratic states and, for all their differences, a foundational consensus on what kind of principles such a response needed to embody. This consensus 
can no longer hold in the contemporary era. Or, at least, it can't be assumed to hold in anything like the way its original and more contemporary defenders assumed.

Cultural diversity, the state's response to immigrants and refugees, and the extent to which nation states can and should be able to police their borders, remain important political issues on the world stage, and also a focus of considerable academic scholarship. The topic of migration in particular has seen a significant growth in the field (e.g. Carens, 2013; Fine \& Ypi, 2016; Wellman \& Cole, 2011). But the migration and multiculturalism literatures are quite separate. The marked increase in interest among political philosophers about the question as to whether, if at all, states can deny entry to immigrants, has not been matched by an similar resurgence in the related question of how any immigrants that are allowed entry into nation states should treated. The two questions - whether we should allow the movement of people across national borders, and how we should treat people once we they have done so - are crucially related in theory and practice, but are not often seen as such in the discipline. This is a problem. While there was never a halcyon era in which citizens of liberal democratic states were wholly open to ideas of cultural recognition and equality, public attitudes towards immigrants and other cultural and religious minorities have visibly hardened since the likes of Rawls, Kymlicka, Tully, Taylor, and Young made their case for a more inclusive polity based on the respect of cultural groups and their practices (Kymlicka, 1997; Rawls, 1993; Taylor, 1994; Tully, 1995; Young, 1990). For sure, a lot of work has been done to build on the classic works in the field which sought to explain and resolve normative debates about diversity, and debates about multiculturalism remain alive, as readers of Ethnicities and other journals will attest (e.g. Meer \& Modood, 2016; Meer et al, 2016; Patten, 2014; Tebble, 2015). But importantly, these earlier works still occupy a foundational place in these debates. Rawls's Political Liberalism, for example, gave rise to a new wave of theorising which emphasised the role of public reason in settling collective political and ethical dilemmas, as well as providing the initial normative background for liberal variants of deliberative democracy, which now dominate Anglo-American democratic 
theory (Cohen, 1989; Gutmann \& Thompson, 2004; Quong, 2010). Kymlicka's work remains very influential to scholars working in the field and also to policy-makers in Canada and beyond (Kymlicka, 1997 \& 2007). And the work of Young, Tully, and Taylor, along with that of Benhabib, Fraser and others, continue to remain important to critics of liberalism who seek a more inclusive politics (Benhabib, 2002; Fraser, 1990).

The majority of the most influential theorists working on the topic of multiculturalism in the 1990s/2000s were engaged in the search for a normative response to cultural and ethical diversity which could be incorporated into the governance of liberal democratic states in the real world. Most obviously, Will Kymlicka brought philosophical debates about identity and autonomy to bear on questions of culture and immigration in order to yield conclusions which could actually be implemented by liberal states, and have been. Similarly, even more abstract thinkers like Young, Taylor, and Tully, whose work drew less on the Rawlsian analytic tradition and more on continental and post-structuralist thinkers like Hegel, Foucault, and the critical theorists of the Frankfurt School, argued for normative ideas which they hoped could be taken up by states in order that members of cultural and religious minority groups might be treated as free and equal agents, for whom cultural membership was a central, non-relinquishable component of their identity and sense of self.

Hence, the question with which I opened this Introduction. Given the apparent desire among what I in this volume have called 'first wave' multiculturalists and their many followers to formulate a realistic response to cultural and ethical diversity which can inform a strategy of political reform in actually-existing states, can we reasonably identify a moment, a threshold point, at which the theories which continue to dominate Anglo-American political theory became untenable in ways which should lead their defenders to question their persuasiveness and fundamental structure? A point at which the assumptions which underpin these approaches become too out of step with reality to be applicable anymore? It would seem that there is, although, as I say, historians will disagree as to when it was. For 
some, it will be the rise of politicised religious identity and terrorism in the late 1990s, and in 2001 in particular. Following the 9/11 attacks on New York's World Trade Centre, the 2004 bombing of Madrid's train line by AI Qaeda, and the 2005 bombing of the public transport system in London, for example, public discourse about religious identity and the incorporation of cultural and religious beliefs into law and policy making shifted away from the kind of multiculturalist view found in a lot of political philosophy, and towards a greater focus on national unity and citizenship as the principal focus of allegiance. In so far as these events caused a political backlash against multiculturalist normative theory, the response is, of course, problematic. Multiculturalist theory didn't advocate the politicisation of religious identities in ways which ground or justify terrorism. Nevertheless, in reality acts of violence around the world served to discredit multiculturalism as a political project in the eyes of many, making the philosophical case for multiculturalism harder to make (Blair, 2006; Cameron, 2011; Parvin, 2009; Phillips, 2004). Kymlicka himself wrote in 2007 that the bloom had 'fallen off the rose of Western liberal multiculturalism' (Kymlicka, 2007; 52) in many liberal democratic states by that point, a claim also made by Anne Phillips among others (Phillips, 2009).

For others, the problem came later, with the growing concerns among many citizens of liberal states about the perceived threat of immigration to jobs and access to public services. Like those about terrorism, these concerns didn't grow out of an engagement with the substance of the multiculturalist position so much as the political debate which attached itself to the idea of 'multiculturalism' as a political project. As economic conditions worsened for many people toward the latter half of the 2000 s, especially in the wake of the 2008 financial crisis, public services in many states became squeezed, jobs became more difficult to find, and people's economic futures became less certain. This, at a time when political leaders and many academics were extolling the virtues of globalisation, the free movement of people and labour, and more flexible borders, as well as the rise of supra-national authorities like the EU which held free movement as central to its political vision, led many citizens and 
academics to turn away from openness toward a focus on social unity and national strength. It was at this time, for example, that thinkers like David Goodhart and David Miller warned of the dangers of too much diversity, and the obstacles that diversity could put in the way of achieving a more progressive, egalitarian political vision, let alone a more conservative one (Goodhart, 2004; Miller, 1997).

For others still, it came even later, with the emergence of populist movements and widespread anti-immigration sentiments across the UK, Europe, and the USA, in part driven by the 'migration crisis' in Europe and the Middle East (Parvin, 2017). That phenomenon, which continues to play out across many European states as well as the USA, represents among other things the hardening of the anti-immigration sentiment that had been evolving for a long time in response not only to the political implications of the 'multiculturalist project' but also the founding ideas at its heart. The global movement of people across and between borders, whether driven by the need to escape dire circumstances at home, or the desire to build new lives and seek new opportunities in different countries, has become demonised by populist leaders, but also by the citizens of many democratic states who afford them support, and who feel (finally) represented by politicians who speak to their concerns rather than marginalised by politicians who speak the language of borderless cosmopolitanism. There has been an explosion in academic interest in populism in recent years, and that literature sits uneasily with the broad sweep of Anglo-American multiculturalist political theory grounded as it is in principles of equality, freedom, and the rational bases of politics.

The world in which we live now is nothing like the world in which Kymicka, Raz, Young, Taylor and the other 'first-wave' multiculturalists developed their theories. It's also nothing like the world in which political liberals like Rawls, Larmore, and Nussbaum made the argument for a form of liberalism which better accommodated diverse comprehensive doctrines associated with the cultural and ethical diversity of modern liberal democratic states (Rawls, 1993; Larmore, 1995; Nussbaum, 1999). The scale of anti-immigrant 
sentiments among many citizens has been a major factor in the explosion of populist movements around the world, the coarsening of public discourse about migration and nationalism throughout the Anglo-American space as well as across Europe, and profound political shocks like the result of the UK referendum on membership of the EU, the election of Donald Trump in the USA, and the success of anti-immigration parties in Europe (Parvin, 2018).

The trajectories of change, of crisis, and of cultural entrenchment that characterise US and European politics over the past three decades have uprooted once-familiar assumptions about the kind of politics that the populations of countries in these regions aspire to and support. What has become clear is that they don't aspire to, or support, the kind of politics that the majority of Anglo-American political theorists, and many academics working in the field of multiculturalist political theory, tend to defend. The gap between a lot of normative political theory on topics including culture, diversity, and migration on the one hand, and the lived experience of politics for millions of people around the world on the other is getting larger: on these questions (and perhaps many others) it seems that many citizens in the real world do not share many of the views of political theorists.

The time seems right, then, to confront this issue, and to discuss what - if anything - political theorists might say about migration and cultural diversity in this new era of populism and anti-immigrant sentiment, and to examine our existing theories in the light of empirical trends. If our aim is at least in part to produce conclusions which might inform political change in actually-existing states, the answer can't be simply to continue to debate these issues as if the world has not changed. Political theorists seeking to inform real political change can't assume that the theories that once held, if they ever did. They can't assume that the assumptions they made about citizens and what they believe still describe citizens as they are now. 
The essays in this symposium address these issues in different ways. They tackle a diverse range of topics, from the openness of borders to cultural appropriation, but are united in seeking to provide new approaches to cultural and ethical diversity, and evaluating the enduring strengths and weaknesses of existing ones.

In my own article, I evaluate the ability of Rawls's political liberalism and Young's politics of difference to provide a coherent and persuasive approach to cultural and ethical diversity in the contemporary era. I argue that neither can offer a persuasive response to the kind of cultural and ethical diversity that now characterises contemporary liberal democratic states. I argue that despite being understood as occupying opposing positions on how to respond to cultural diversity, political liberalism and the politics of difference actually share a number of important normative assumptions which mean that they are better understood as variants of the same approach. In particular, I argue, both try to provide a realistic approach to the problems associated with diversity which is capable of actually resolving some of the problems facing liberal states in a way that captures the lived reality of these states. I then argue that neither approach is compelling or realistic because both are grounded in assumptions which no longer fit the contemporary era. In particular, I suggest that the form of democratic dialogue that we find in these theories requires individuals to think and act in ways that they can't or won't. The kind of democratic decision making process envisaged by political liberals like Rawls and also difference theorists like Young, in which citizens engage in debate with others who they understand as free and equal, is out of kilter with a contemporary reality in which many citizens do not or cannot adopt a reasonable perspective with regard to their own ends or the ends of others and do not view other parties as necessarily free or equal. Far from being a small group who exist on the peripheries of liberal states, the 'unreasonable' now comprise a significant proportion of the populations of liberal states. Neither defenders of a politics of difference nor political liberals can cope with the fact that citizens don't possess the cognitive resources to participate in democratic debate and deliberation in the way they require or hold the values that they need them to. 
Liberal states have, over the past two decades, become less liberal, less tolerant of diversity, and more concerned to protect the values of the national majority at the expense of the rights of minority groups. Citizens in many liberal states do not believe that members of minority cultures or immigrant communities should be understood as free to practice their beliefs or that they are of equal status to them. Migrant communities have come under increased pressure in the past two decades to assimilate to the wider culture, and to hide or to abandon their traditional cultural practices. Iris Marion Young believed that democracy could be a means of establishing a just society. Rawls believed that democratic dialogue could produce legitimate outcomes which would be fair to diverse groups and also grounded in liberal principles of freedom and equality. I suggest that neither approach is viable in a world characterised by anti-immigration sentiments, 'unreasonable' citizens, and the denial of the freedom and equality of minority groups by many members of liberal democratic states. I argue that this fact presents political philosophers with a stark choice between establishing a just society (and hence, a theory which is unrealistic in the sense that it cannot be applied to the political reality of the early $21^{\text {st }}$ Century), and establishing a democratic one (which is more realistic, but which will produce outcomes which are contrary to what many political philosophers would defend).

Gabriele Badano and Alasia Nuti are more optimistic about the ability of political liberalism to respond to the fact of cultural and ethical diversity. Political liberalism can respond to diversity, they argue, but in order to do so political liberals must reject the idea that liberal public reason can include 'reasoning from conjecture'. This view has become increasingly popular among post-Rawlsian political liberals, and is essentially the idea that the process of public reasoning among citizens of liberal democratic states can include particular forms of engagement with comprehensive doctrines. On this view, it's possible and appropriate to seek to clarify the religious beliefs of different parties to the political dialogue, and to challenge mistakes or inconsistencies in the substance of these views, in order to bring the unreasonable within the bounds of what is permissible in a liberal society. It's permissible for 
political liberals to challenge Islamists and other religious extremists on their views - to apply reason to these views in ways which expose inconsistencies or logical fallacies - as a way of encouraging unreasonable citizens to be more reasonable. Such a view is consistent with the deeper normative commitments of political liberalism, defenders say. Parties arguing 'from conjecture' in this way aren't seeking to denigrate the views of others, and they are not denying anyone's basic freedom or equality. They are simply pointing out the existence of logical or factual inconsistencies in the beliefs of others, and the implications of these inconsistencies. This view is controversial, of course, in that it suggests contra Rawls that while substantive ethical disagreement among citizens holding diverse comprehensive doctrines will be inevitable and permanent on the grounds that tensions between them cannot be resolved by appeals to reason, their effects can be minimised by reason. Public reason cannot establish that one particular religion is true while the others are false, but it can expose certain kinds of inconsistencies or mistakes in the belief systems of those involved. This fact means that public reason can be used as a means of reducing the number of unreasonable people, encouraging the unreasonable to be more accommodating in the way they approach the resolution of political questions, and also, perhaps most importantly, countering the tendency for radicalisation. Public reason can be employed as a mechanism for convincing adherents to radical religious and other comprehensive doctrines to become loyal to the values of liberal democracy.

Badano and Nuti argue that the 'reasoning from conjecture' approach is mistaken for a number of reasons, not least that it's far too optimistic about the capacity of adherents to radical religious doctrines to accept the inconsistencies which public reason reveals. Like me, Badano and Nuti believe that political liberalism understood in this way is too demanding of citizens, and requires too much of them. Citizens are very unlikely to hold fully worked-out, systematic comprehensive doctrines, and so they are unlikely to be moved when inconsistencies are pointed out to them. Furthermore, empirical studies suggest that the root causes of radicalisation tend to be economic and social, rather than doctrinal. Unlike 
me, however, they argue that political liberalism can be saved if it's re-focused more on creating conditions for the exercise of a more aspirational form of citizenship which enables citizens to think about what kind of citizens they want to be.

The claim, found in my own piece and also Badano \& Nuti's, that cultural or religious beliefs exist beyond the scope of reason, and that it is somehow impossible for members of different groups to engage with, or even understand, the views of others is anathema to a growing number of academics and politicians who adopt an 'intercultural', rather than a 'multicultural' perspective on diversity (e.g. Bennett, 1998). Interculturalism sets itself against the idea that cultures are discrete groups, and suggests instead that members of different cultures can and should engage with one another on the substance of their views in order to forge a more unifying politics which moves beyond the instability and divisiveness that is common to many forms of identity politics. It's an open question, however, whether interculturalism is a genuine advance on conventional multiculturalist theory, and also whether support for it is driven by political rather than philosophical concerns (Modood, 2011). Critics have argued that interculturalism has been especially popular among politicians who seek to use the vocabulary of multiculturalism while pushing a more explicitly integrationist policy than many multiculturalists would support (Kymlicka, 2015). Defenders suggest that a policy of active engagement among diverse groups offers a deeper, richer approach to cultural diversity than the kind of 'passive tolerance' of group differences that we find in political liberalism.

These claims are a central concern for Avigail Eisenberg who analyses the differences between interculturalism and multiculturalism in the context of recent political developments in Canada, and also wider debates about the rights of majorities. Eisenberg suggests that the popularity of interculturalism over multiculturalism in Quebec is at least partly explained by the deeper concern for the protection of national values in that region than in other parts of Canada, and a deeper concern for protecting the rights of the majority. Multiculturalism 
has, rightly or wrongly, been understood by many as offering a relativist vision of politics in which discrete cultural groups need not engage with, or value, the values of other groups. Such an approach is inhospitable to any politics which seeks to establish a wider sense of national allegiance over and above allegiance to one's cultural group. Interculturalism on the other hand requires members of minority cultures to engage with other cultural values, including the wider national values of the political community in which they live. Eisenberg argues that the adoption of interculturalism by the Quebec government enables them to restrict minority rights, and subordinate them to wider majority values. Rising fears about the supposed dark side of multiculturalism among citizens of many liberal democratic states, and the rise in populism and anti-immigration rhetoric among politicians that these fears have fuelled, have put the relationship between minority and majority cultural values into the foreground of political discourse, uprooting conventional multiculturalist theorising which has tended to be focused on protecting minority cultures above all else. Eisenberg explores this issue in the context of contemporary developments, and in particular discusses what, if any, rights to special treatment are enjoyed by majorities vis a vis minorities.

Interculturalism, multiculturalism, political liberalism, and the politics of difference all attempt to make sense of the ways in which members of different cultures can be expected to engage with one another, to understand one another, and to come together within a common polity. Their focus is on the extent to which cultures might engage with one another in ways which lead to fair political decisions as well as a political regime grounded in principles of freedom and equality. Peter Balint and Patti Lenard focus on a different aspect of cultural engagement: the ways in which members of different groups might be said to absorb or 'appropriate' the values or practices of other groups into the lived experience of their own culture, either deliberately or unintentionally. Jeremy Waldron was arguably the first in the Anglo-American tradition of political philosophy to emphasise the ways in which cultures are in some sense comprise multiple cultural artefacts and fragments (Waldron, 1992). His cosmopolitan theory of cultural identity, emerging as it did during the first wave of 
multiculturalist theory, was intended as a riposte to liberal thinkers like Will Kymlicka would emphasised the need for individuals to be members of discrete cultures characterised by their own practices and ideals (Kymlicka, 1997; Raz, 1996). This 'communitarian' understanding of culture did not fit the real world, Waldron argued. The cultures to which people belong in the contemporary era are not discrete or pure entities, ring-fenced from one another and in need of state protection. They are internally diverse and incorporate elements of many different cultures. This is especially true of western liberal culture, the composition of which has altered and benefited greatly from global migration: the background culture to which we cleave in liberal democratic societies, and which provide us with our perspective on the world, are shot through with diversity, and are characterised by all kinds of cultural influences which are sometimes acknowledged and sometimes not.

Waldron's cosmopolitanism offered an optimistic view of liberal society and the value that minority cultures could bring to it. But his view ignored a possible dark side to cosmopolitanism. On Waldron's view, liberal culture 'draws on' and 'incorporates' the best that other cultures can offer and, in doing so, makes liberal society richer. But liberal culture may not be the benign force that he outlines. Indeed, history would paint liberalism and 'western culture' much more harshly than he himself does. The cultural practices and artefacts that comprise liberal culture were often not absorbed through productive cultural engagement, but through imperialism, colonial repression, and theft. Most obviously, British and American museums are full of artefacts which were taken from the cultures which created them. Less obviously, some argue, western culture has 'appropriated' the practices of other cultures and incorporated them in ways which wrench them from their original context and change their meaning. When Caucasian men or women wear their hair in cornrows, or when self-styled gurus teach Yoga without talking into account the historical, cultural, and spiritual roots of the practice, or when people wear culturally-specific garments like the hijab or the native American head dress as fashion accessories, they are appropriating elements of minority cultures in ways which are wrong and sometimes 
offensive, especially if, as is so often the case, the meaning of these artefacts for these cultures and more widely are intertwined with the legacy of colonialism, repression, and/or racism.

The debate surrounding cultural appropriation provides a new perspective on the central question presented in this volume: how should we understand culture, and respond to cultural diversity, in an age which is increasingly characterised by an antipathy among citizens and governments about these things? The charge of appropriation is controversial, especially among commentators on the right who see it as a consequence of a pernicious form of identity-politics, a means of closing down debate and policing people's dress and other choices (e.g. Malik, 2017). This is an important debate, but it's also one in which context matters. The inclusion of cultural artefacts in the general background culture of liberalism tends to alter its meaning: its meaning is no longer determined by its place in the culture in which it originated, but by the liberal culture that it is entering. Cornrows become just another hair style, rather than one common among black people under pressure to confirm to white appearance norms; the hijab becomes a fashion item, rather than an expression, or a requirement, of certain religious beliefs; and yoga becomes just another way for the affluent middle classes to get fit, losing its historical and traditional character. In changing their meaning in this way, it becomes much easier for majority cultures to enjoy the benefits of traditional cultural and historical practices without having to acknowledge that they were once part of a different culture. Having 'appropriated' them for themselves, majority cultures can continue to enjoy their benefits while at the same time rejecting or hating the migrant cultures that provided them. The British can express hatred for Pakistanis or Indian people while enjoying their cuisine, because they don't see the link between the people and the food, so ingrained in British culture Indian food has become. And US citizens can do the same about Mexican immigrants. Waldron and other cosmopolitan liberals may be right that liberal culture is suffused with multiple and diverse cultural influences. But the more incorporated they become into the wider liberal culture - the more their meaning is 
determined for members of that liberal culture by the liberal culture and not the culture that created them - the easier it becomes for majority cultures in liberal states to demonise the people while enjoying their cultural practices.

Balint \& Lenard provide a conceptual analysis of cultural appropriation in their piece for this volume, in order that we might get a clearer sense of what cultural appropriation is and what, if anything, is wrong with it. In general, their view is that cultural appropriation is not the major problem that many believe it to be. They argue that many of the most egregious forms of appropriation are not cases of appropriation at all, but rather something else like theft. Balint \& Lenard argue that, once we fully understand what counts as appropriation rather than, say, theft or some other act, the force of the critique against appropriation is weakened. Once again, however, context matters. Appropriation can indeed become a problem in the presence of certain 'amplifiers'. For example, if a company exploits cultural practices for profit, or if they engage in the cultural practices of others without the consent of those other groups, or if there is a clear power imbalance between the original culture and the culture that wants access to their practices. In these circumstances, which Balint \& Lenard analyse in depth, there are particular reasons to be concerned about appropriation.

Finally, Adam Tebble provides an original take on the question of open-borders and migration in the context of wider scepticism about these things among citizens of many liberal democratic states. Much of the public discourse around the movement of people has concerned the 'problem' of immigration: the perceived threat among many citizens to jobs, public services, and so on, which arise as a result of an influx of new people who clog up the system. However, numerous others (business owners, health providers, etc.) have warned of the dangers of emigration, especially among skilled workers. Open borders and the free movement of people can have a negative impact on nation states which rely on the skills and experience of immigrants. For people worried about emigration and the problem of 'brain drain', open borders are a potential threat for entirely opposite reasons to those 
worried about immigration: the problem with open borders isn't so much that immigrants arrive, take people's jobs, and exert pressure on public services, it's that they allow people to take their skills and experience abroad, leaving states incapable of delivering public services to those that remain. As doctors and nurses leave the UK, so the NHS becomes less able to provide the kind of access to, and quality of, healthcare that it is required to, and so on. Tebble confronts this issue, and discusses the role that the interests of those 'left behind' my exiting migrants can and should have in our normative theorising, and how concerns about emigration and 'brain drain' connect with wider debates about the views of contemporary citizens about the movement of people across borders, but also about immigration in a changing global context.

In general, it seems, many citizens of liberal democratic states appear explicitly committed to the need for unskilled people to 'go back home' (even if their current place of residence is, and has always been, their home), and also to the denial of entry to new unskilled migrants. But it's not so clear what their views are - or should be - with regard to skilled migrants or skilled members of cultural minorities. Is there a sense among them that skilled migrants should be allowed entry? Is there a sense that states should be more hospitable to skilled minorities? And is there, more controversially, a sense in which states should in fact make it more difficult for such minorities to leave? Does the rhetoric of global cosmopolitanism and open borders popular among many political theorists lead to the impoverishment of some states? And how does all this fit in a world in citizens' views about these things are changing so radically and obviously?

Debates about multiculturalism are crucial in the contemporary era. Issues of cultural and religious diversity are at the heart of many of the most significant political developments in the early $21^{\text {st }}$ Century, and figure (either implicitly or explicitly) in the major areas of concern for political philosophers, from migration and borders, to public reason, deliberative democracy, and the bases of liberal legitimacy. The point is that the world, and the views of 
liberal democratic citizens, are changing in ways which threaten the persuasiveness of canonical multiculturalist theories, and their implications for normative political theory and public policy, even among those who once believed and defended them. The liberal multiculturalist theories of Kymlicka, Rawls et al, and the non-liberal ones of Young, Taylor, and Tully et al, as well as all the other ones which came later but drew on these theories for their inspiration are not, in general, works of ideal theory. They identify a concrete problem characteristic of actually-existing states, and seek normative solutions to that problem that they hope can help to shape real-world decision making and institutional design. They don't exist independently of the world in which they were formed. They are informed by that world, arise out of it, and seek solutions which, if implemented, would resolve tensions between cultural and religious groups on terms consistent with wider principles of fairness or justice or something else. As the world changes, and as citizens change, so theories must either change or show how real-world changes can be accommodated within the theories as they are. The theories of multiculturalism that have dominated political theory for so long, and which continue to influence and inspire a new generation of scholars, can't be simply applied to the world in which we now live, or at least, we shouldn't simply assume that they can. This volume merely seeks to begin this process of re-appraisal and re-interpretation and, hopefully, spark new debate about these issues and the search for a normative response to cultural and religious diversity in liberal democratic states.

Bibliography

Benhabib, S. (2002) The Claims of Culture: Equality and Diversity ion the Global Era (Princeton, NJ: Princeton University Press).

Bennett, M. J. (ed.) Basic Concepts of Intercultural Communication (London|: Intercultural Press). 
Blair, T. (2006) 'Multiculturalism and Integration', speech given to the Runymede Trust, $8^{\text {th }}$ December.

Carens, J. (2013) The Ethics of Immigration (Oxford: Oxford University Press).

Cameron, D. (2011) Prime Minister's Speech at the Munich Security Conference, Delivered $5^{\text {th }}$ Feb. Available: https://www.gov.uk/government/speeches/pms-speech-at-munichsecurity-conference

Cohen, J. H. (1989) 'Deliberation and Democratic Legitimacy' in A. Hamlin \& P. Pettits (eds) The Good Polity: Normative Analysis of the State (New York: Blackwell).

Fine, S. \& L. Ypi (2016) Migration in Political Theory: The Ethics iof Movement and Membership (Oxford: Oxford University Press).

Goodhart, D. (2004) ‘Too Diverse?’, Prospect, Feb. Available: https://bit.ly/2s94Wrt

Gutmann, A. \& D. Thompson (2004) Why Deliberative Democracy? (Princeton, NJ: Princeton University Press).

Kymlicka, W. (2015) 'Defending Diversity in an Era of Populism: Multiculturalism and Interculturalism Compared', in N. Meer et al (eds.) Multiculturalism and Interculturalism: Debating the Dividing Lines (Edinburgh: Edinburgh University Press).

Kymlicka, W. (2007) Multicultural Odysseys: Navigating the New International Politics of Diversity. Oxford: Clarendon Press.

Kymlicka, W. (1997) Multicultural Citizenship: A Liberal Theory of Minority Rights (Oxford: Clarendon Press).

Larmore, C. (1995) The Morals of Modernity (Cambridge: Cambridge University Press).

Malik, K. (2017) 'In Defense of Cultural Appropriation', The New York Times, June 14 th Available:| https://nyti.ms/2sB10pJ

Meer et al eds. (2016) Multiculturalism and Interculturalism: Debating the Dividing Lines (Edinburgh: Edinburgh University Press).

Meer \& Modood (2016) 'How does Interculturalism Contrast with Multiculturalism?', Journal of Intercultural Studies 33/2, pp. 175-196.

Nussbaum, M. (1999) 'A Plea for Complexity' in Joshua Cohen, Matthew Howard, \& Martha Nussbaum (eds.) Is Multiculturalism Bad for Women? (Princeton, NJ: Princeton University Press).

Parvin, P. (2018) 'Representing the people: British democracy in an age of political ignorance', Political Studies Review. Published online: http://bit.ly/2pgkBCQ.

Parvin, P. (2017) 'Idealism, realism, and immigration: David Miller's Strangers in Our Midst', Critical Review of International, Social, and Political Philosophy 20/6. Published online (2016): http://bit.ly/2gTRVvL. 
Parvin, P. (2009) 'Identity and integration in an international context: Problems and ambiguities in the new politics of multiculturalism', Political Studies Review 7/3. Published online: http://bit.ly/2ryOjHN

Parvin, P. (2008) 'What's Special About Culture? Identity, Autonomy, and Public Reason', Critical Review of International, Social, and Political Philosophy 11 (3), pp. $315-334$.

Patten, A. (2014) Equal Recognition: The Moral Foundations of Minority Rights (Princeton, NJ: Princeton University Press).

Phillips, T. (2004) 'Britain Must Scrap Multiculturalism' by Tom Baldwin and Gabriel Rozenburg in The Times, April $3^{\text {rd }}$. Available from:

http://www.timesonline.co.uk/tol/news/uk/article1055221.ece

Phillips, A. (2009) Multiculturalism Without Culture (Princeton, NJ: Princeton University Press).

Quong, J. (2010) Liberalism Without Perfection (Oxford: Oxford University Press).

Rawls, J. (1993) Political Liberalism (New York: Columbia University Press).

Raz, J. (1998) 'Multiculturalism', Ratio Juris 11/3, pp. 193-205

Raz, J. (1986) The Morality of Freedom (Oxford: Clarendon Press).

Tebble, A. (2017) Epistemic Liberalism: A Defence (London: Routledge).

Tully, J. (1995) Strange Multiplicity: Constitutionalism in an Age of Diversity (Cambridge: Cambridge University Press).

Waldron, J. (1992) 'Minority Cultures and the Cosmopolitan Alternative', University of Michigan Journal of Law Reform 25, pp. 93-119.

Young, I. M. (1990) Justice and the Politics of Difference (Princeton, NJ: Princeton University Press). 